9. Карташов С. В. Объективные признаки состава преступления, сопряженного со злостным уклонением от погашения кредиторской задолженности (ст. 177 УК РФ) // Актуальные проблемы государства и права. 2020. T. 4. № 15. С. 327-347. DOI 10.20310/2587-9340-2020-4-15-327-347. URL: https:// elibrary.ru/ (дата обращения: 12.07.2021).

10. Методические рекомендации по выявлению и расследованию преступлений, предусмотренных ст. 177 Уголовного кодекса РФ (злостное уклонение от погашения кредиторской задолженности)» (утв. ФССП России 21.08.2013 № 04-12) (ред. от 03.10.2016) // СПС «КонсультантПлюс» (дата обращения: 12.07.2021).

11. Раздел статистики Росстата: «Рынок труда, занятость и заработная плата». URL: https://rosstat. gov.ru/labor_market_employment_salaries (дата обращения: 15.09.2021).

12. Статья. URL: https://www.gazeta.ru/business/2019/08/07/12562459.shtml (дата обращения: 15.09.2021).

13. Статья. URL: https://www.rbc.ru/business/16/12/2020/5fd8d3749a79473c3e574c70 (дата обращения: 15.09.2021).

14. Статья. URL: https://rg.ru/2019/12/10/stalo-izvestno-skolko-rossiian-poluchaiut-zarplaty-vkonverte.html (дата обращения: 15.09.2021).

15. Статья. URL: https://www.kommersant.ru/doc/4639667 (дата обращения: 15.09.2021).

16. Уголовно-процессуальный кодекс Российской Федерации от 18.12.2001 № 174-Ф3 (ред. от 01.07.2021) // СПС «КонсультантПлюс» (дата обращения 15.09.2021).

17. Лавров В.П., Победкин А.В. Проверка сообщения о преступлении: условия конституционности // Юридическая наука и практика: Вестник Нижегородской академии МВД России. 2018. № 2 (42). C. 194-198. URL: https://www.elibrary.ru/ (дата обращения: 12.07.2021).

18. Гаврилов Б. Я. Влияние института возбуждения уголовного дела на состояние борьбы с преступностью // Актуальные проблемы борьбы с преступностью: вопросы теории и практики : мат-лы XXIV Междунар. науч.-практич. конф., Красноярск, 08-09 апреля 2021 г. Красноярск : Сибирский юридический институт МВД РФ, 2021. C. 175-177. DOI 10.51980/2021_1_175. URL: https://www.elibrary. $\mathrm{ru/}$ (дата обращения: 12.07.2021).

19. Деришев Ю.В. Реликт социалистической законности мутирует // Российское право: образование, практика, наука. 2017. № 6 (102). C. 71-76. URL: https://www.elibrary.ru/ (дата обращения: 12.07.2021).

20. Володина Л. М. Проблемы регламентации возбуждения уголовного дела // Библиотека криминалиста. 2013. № 4 (9). С. 5-11. URL: https://www.elibrary.ru/ (дата обращения: 12.07.2021).

\title{
АНАЛИЗ ДИНАМИКИ РОСТА СТЕПЕНИ ВОВЛЕЧЕННОСТИ В АНТИТЕРРОРИСТИЧЕСКУЮ ДЕЯТЕЛЬНОСТЬ ПРЕПОДАВАТЕЛЕЙ И СТУДЕНТОВ АЛТАЙСКОГО КРАЯ 3А 2020-2021 ГГ.
}

\author{
М. А. Стародубцева \\ Алтайский государственный университет (Барнаул, Россия)
}

Одновременно с началом пандемии коронавирусной инфекции и введением дистанционного формата обучения по всей России непрерывно идет процесс работы с преподавателями и студентами по их адаптации в цифровой среде. В полной мере данный процесс затронул и Алтайский край, где роль флагмана высшего образования отдана Алтайскому государственному университету. Уни- 
верситет с момента начала пандемии 2020 г. активно включился в сферу дистанционного обучения и начал применять цифровые методы общения со студентами. Были проведены десятки научно-практических конференций в онлайн-формате, что позволило существенно сгладить процесс адаптации к новой цифровой сфере как у преподавателей, так и у студентов.

Соответственно, увеличение знаний о цифровом мире пробудило интерес к цифровым технологиям и адаптации их для нужд криминологии, напрямую занимающейся анализом и прогнозированием противодействия кибертерроризму. Ожидается, что рост вовлечения преподавателей в цифровую среду повлечет за собой рост правового просвещения и обучаемой ими молодежи.

Молодежь, являющаяся активным пользователем сети Интернет и выступающая в связи с этим объектом онлайн-вербовки в террористические и экстремистские организации, заинтересована в получении знаний о противодействии подобным явлениям.

Для подтверждения выдвинутых тезисов нами было проведено криминологическое исследование степени вовлеченности студентов и преподавателей Алтайского края в контрпропагандистскую деятельность в условиях частично дистанционного взаимодействия. В данной статье мы отражаем основные результаты проделанной работы.

Ключевые слова: терроризм, кибертерроризм, криминологическое исследование, гражданскопатриотическая работа, контрпропагандистская деятельность, цифровое взаимодействие, студенческие организации.

\title{
ANALYSIS OF THE DYNAMICS OF THE GROWTH OF THE DEGREE OF INVOLVEMENT IN THE ANTI-TERRORIST ACTIVITIES OF TEACHERS AND STUDENTS OF THE ALTAI REGION FOR 2020-2021
}

\author{
M. A. Starodubtseva \\ Altai State University (Barnaul, Russia)
}

Simultaneously with the beginning of the coronavirus pandemic and the introduction of a distance learning format throughout Russia, the process of working with teachers and students to adapt them in the digital environment is continuously ongoing. This process fully affected the Altai Territory, where the role of the flagship of higher education was given to the Altai State University. Since the beginning of the 2020 pandemic, the university has actively engaged in the field of distance learning and began to apply digital methods of communication with students. Dozens of scientific and practical conferences were held in an online format, which made it possible to significantly smooth the process of adaptation to the new digital sphere for both teachers and students.

Accordingly, the increase in knowledge about the digital world has prompted interest in digital technologies and their adaptation for the needs of criminology, which is directly involved in the analysis and forecasting of countering cyber terrorism. It is expected that the increased involvement of teachers in the digital environment will lead to an increase in legal education and the youth they teach.

Young people who are an active user of the Internet and, in this regard, are the object of online recruitment into terrorist and extremist organizations, are interested in gaining knowledge about countering such actions.

To confirm the theses put forward, we carried out a criminological study of the degree of involvement of students and teachers of the Altai Territory in counter-propaganda activities in the context of partially remote interaction. In this article, we reflect the main results of our work.

Keywords: terrorism, cyber terrorism, criminological research, civil and patriotic work, counterpropaganda activities, digital interaction, student organizations.

Doi: https://doi.org/10.14258/ralj(2021)3.6 
$\mathrm{B}$ 2021 г. произошел качественный скачок в привлечении преподавателей российских вузов к разработке новых образовательных курсов с использованием технологий дистанционного обучения и взаимодействия, налажена в рекордно короткие сроки система обучения преподавательского состава Digital technology на платформах «Университет 20.35», «Университет Иннополис». Отмеченные программы и курсы позволили адаптировать большинство преподавателей к реалиям цифрового мира и помогли возобновить частично прерванный научный процесс. Особенно это касается сферы уголовного права и криминологии, оказавшейся на передовой разработки антитеррористической идеологии среди молодежи [1, с. 18].

В полной мере данный процесс затронул и Алтайский край, где роль флагмана высшего образования отдана Алтайскому государственному университету. Университет с момента начала пандемии 2020 г. активно включился в сферу дистанционного обучения и начал применять цифровые методы общения со студентами. Были проведены десятки научно-практических конференций в онлайн-формате, что позволило существенно сгладить процесс адаптации к новой цифровой сфере как у преподавателей, так и у студентов.

Соответственно, увеличение знаний о цифровом мире пробудило интерес к цифровым технологиям и адаптации их для нужд криминологии, напрямую занимающейся анализом и прогнозированием противодействия кибертерроризму. Ожидается, что рост вовлечения преподавателей в цифровую среду повлечет за собой рост правового просвещения и обучаемой ими молодежи [2, c. 9].

Молодежь, являющаяся активным пользователем сети Интернет и выступающая в связи с этим объектом онлайн-вербовки в террористические и экстремистские организации, заинтересована в получении знаний о противодействии подобным явлениям [3, с. 8].

Для подтверждения выдвинутых тезисов нами было проведено криминологическое исследование степени вовлеченности студентов и преподавателей Алтайского края в контрпропагандистскую деятельность в условиях частично дистанционного взаимодействия.

На первом этапе в исследовании приняли участие 103 студента колледжей г. Барнаула (колледж АлтГУ, Алтайский промышленно-экономический колледж), и 50 респондентов из числа преподавательского состава. Возраст респондентов первой группы - 15-17 лет, возраст второй группы - 3050 лет.

Охарактеризуем основные результаты первого этапа исследования. Основными причинами терроризма студенты и преподаватели указали целенаправленное «разжигание» представителями экстремистски настроенных и террористических организаций националистической агрессии (38\% и $42 \%$ соответственно), напряженную социальную и экономическую обстановку в стране (18\% и 8\%), низкий уровень правовой культуры и недостаточную степень толерантности населения (14\% и 24\% соответственно). Можно сделать промежуточный вывод, что среди участников обеих выборок преобладает пока еще традиционное представление об образе террориста (рис. 1). Однако на сегодняшний день терроризм постепенно «меняет лицо»: в террористические организации вербуют не только религиозных фанатиков с ярко выраженной националистической агрессией, но и подростков с несформированной психической картиной мира и нечеткой гражданской позицией [4, c. 48].

Далее мы проанализировали мнения студентов и преподавателей относительно необходимости работы в контрпропагандистском направлении в сети Интернет. 74\% опрошенных в обеих выборках указали, что принимают меры для ограждения себя от террористической пропаганды в сети Интернет. Игнорируют сообщества с выраженной террористической тематикой, соответственно, 50\% студентов и $68 \%$ преподавателей. Однако при этом не уточняются критерии признания сетевого сообщества террористическим. Жалобы на пользователей / сообщества / сайты, которые, на взгляд респондентов, ведут террористическую деятельность, оставляют $27 \%$ и $29 \%$ респондентов. Контрпропагандистской деятельностью в сети Интернет готовы заниматься $2 \%$ студентов и $3 \%$ преподавателей. По нашему мнению, это шаг вперед в совершенствовании мер профилактики терроризма и иных деструктивных идеологий в сети Интернет, знак участия гражданского общества в решении обозначенной нами проблемы. Однако эта же цифра показывает нам весьма незначительное количество пользователей сети Интернет среди студенческой молодежи и преподавательского состава, готовых действительно бороться с террористической пропагандой (рис. 2). Это означает необходимость дальнейшей работы в указанном направлении [5, с. 1181]. 


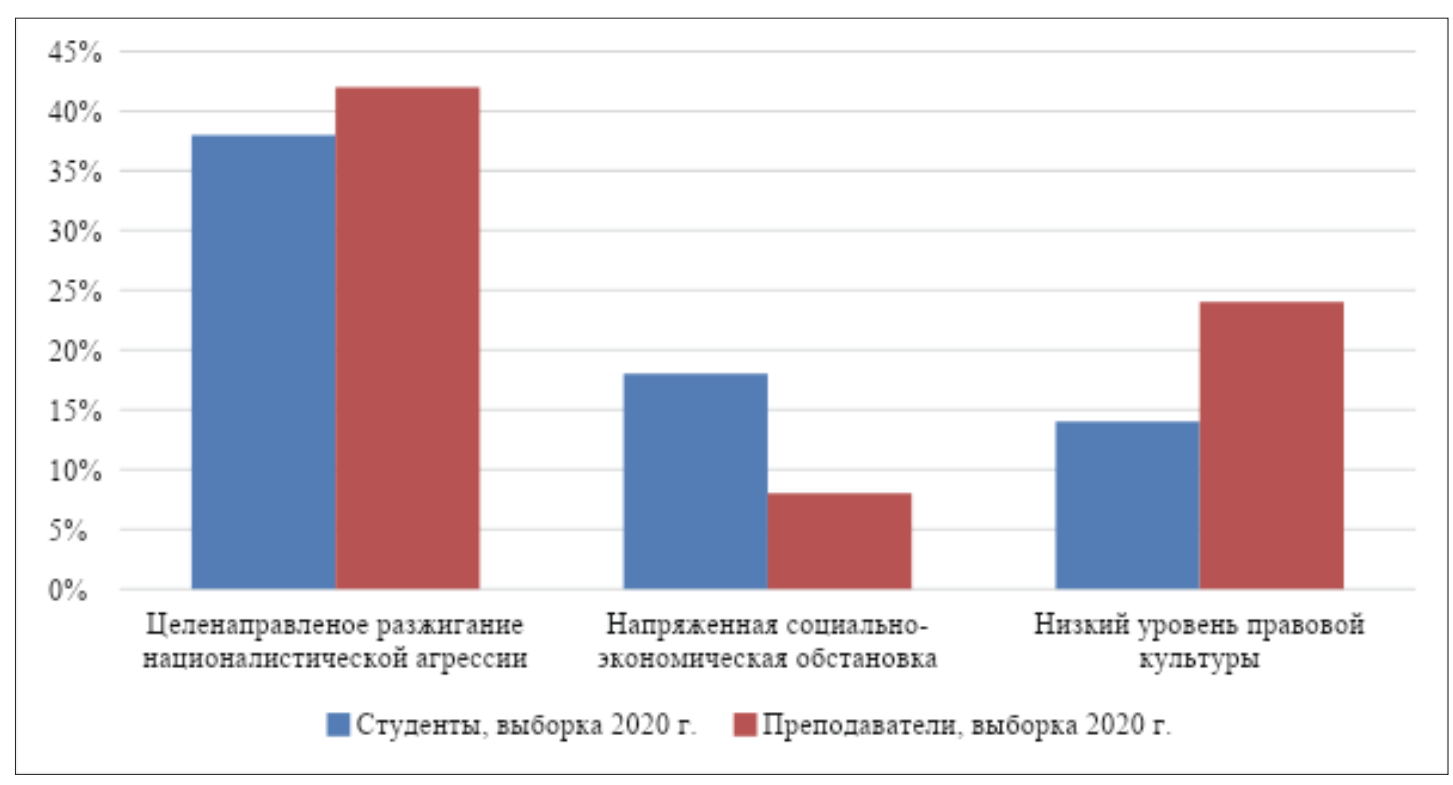

Рис. 1. Анализ мнений студентов и преподавателей относительно основных причин распространения идеологии терроризма (2020 г.)

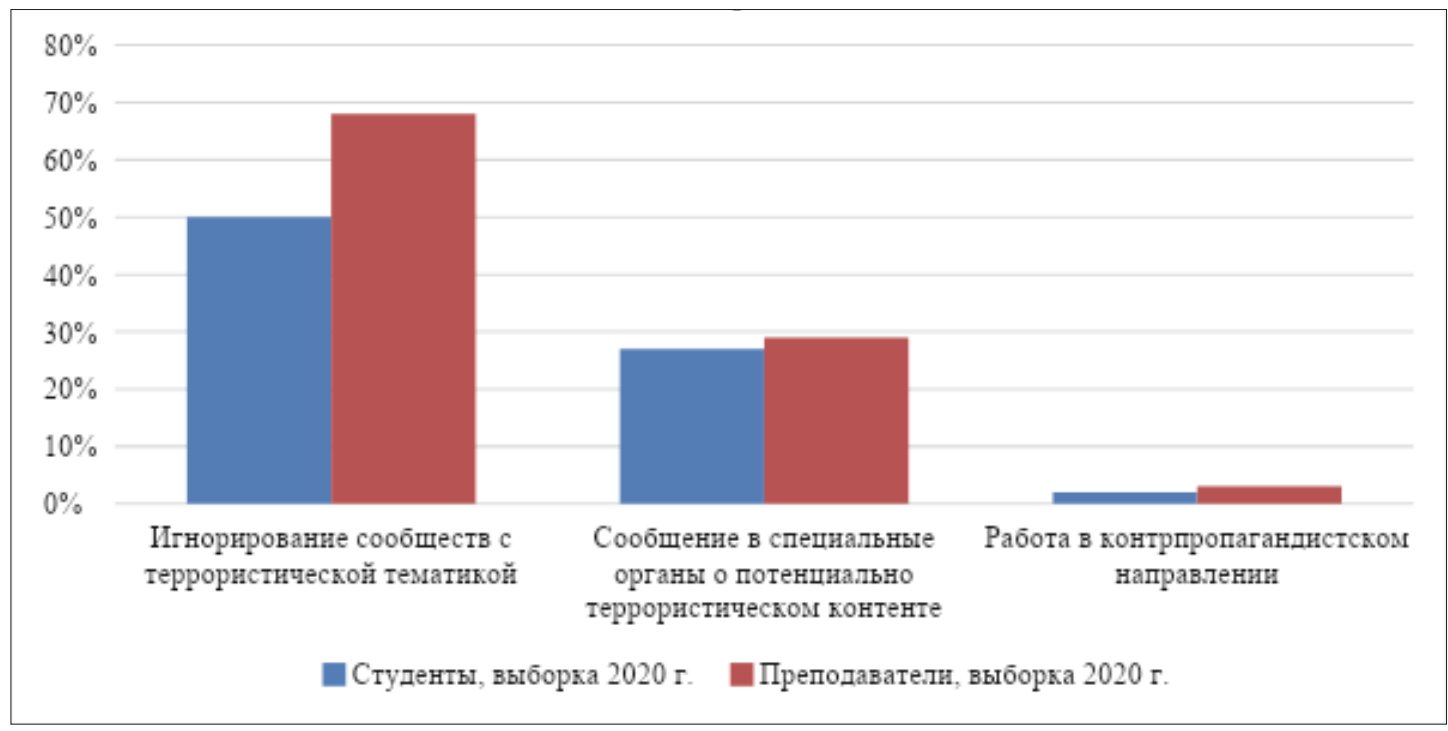

Рис. 2. Анализ мнений студентов и преподавателей относительно необходимости работы в контрпропагандистском направлении в сети Интернет

Следующей вехой нашего исследования было определение спектра мнений относительно необходимости осуществления мероприятий по профилактике терроризма и кибертерроризма в образовательных учреждениях (рис. 3). Здесь по итогам изучения 2020-2021 гг. мы можем наблюдать заметную динамику.

На момент осени 2020 г. 69\% педагогов знают о программах мероприятий по профилактике экстремизма и идеологии терроризма и кибертерроризма в их образовательных учреждениях. Однако $31 \%$ ответил отказом, что означает невовлеченность в подобные мероприятия практически трети педагогического состава. Это можно объяснить как большой нагрузкой, так и неосведомленностью либо нежеланием учителей тратить время на правовое просвещение. 48,3\% респондентов-преподавателей отметили, что не участвуют в подобных мероприятиях, соответственно, не участвуют и их кураторские группы / классы [6, с. 411]. 


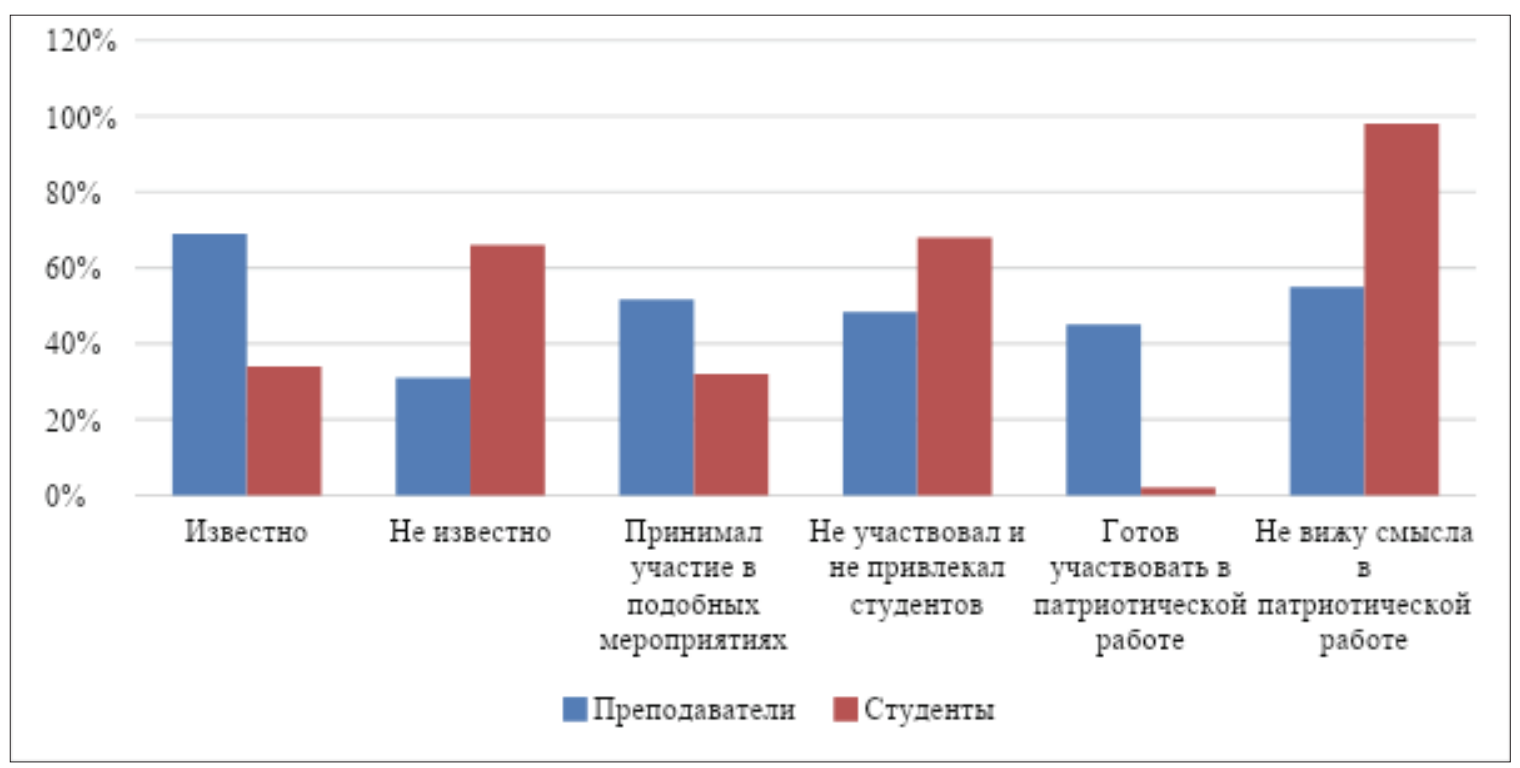

Рис. 3. Анализ мнений студентов и преподавателей относительно необходимости осуществления мероприятий по профилактике терроризма и кибертерроризма в образовательных учреждениях (2020 г.)

Поэтому мы выделили «группу риска» лиц, не знающих о проявлениях экстремизма и способных подпасть под влияние потенциальных вербовщиков [7, с. 155].

После подведения итогов первого этапа исследования мы приступили к организации работы с преподавателями и студентами колледжа АлтГУ. Нами были проведены 8 гражданско-патриотических мероприятий в формате лекций и круглых столов, касающихся правового просвещения учеников и преподавателей, из них 3 непосредственно для преподавателей. На базе колледжа АлтГУ круглые столы по правовому просвещению мы сделали ежегодными и добились включения их в календарный план воспитательной работы колледжа. Также по нашей инициативе в колледже открылись ячейка волонтерской организации Юридического института АлтГУ «Антиэкстремизм», собственная волонтерская организация «АКТО», активно участвующие в процессе работы с первокурсниками колледжа в рамках гражданско-патриотического воспитания. На данный момент работа ведется полностью в цифровом формате [8, с. 106].

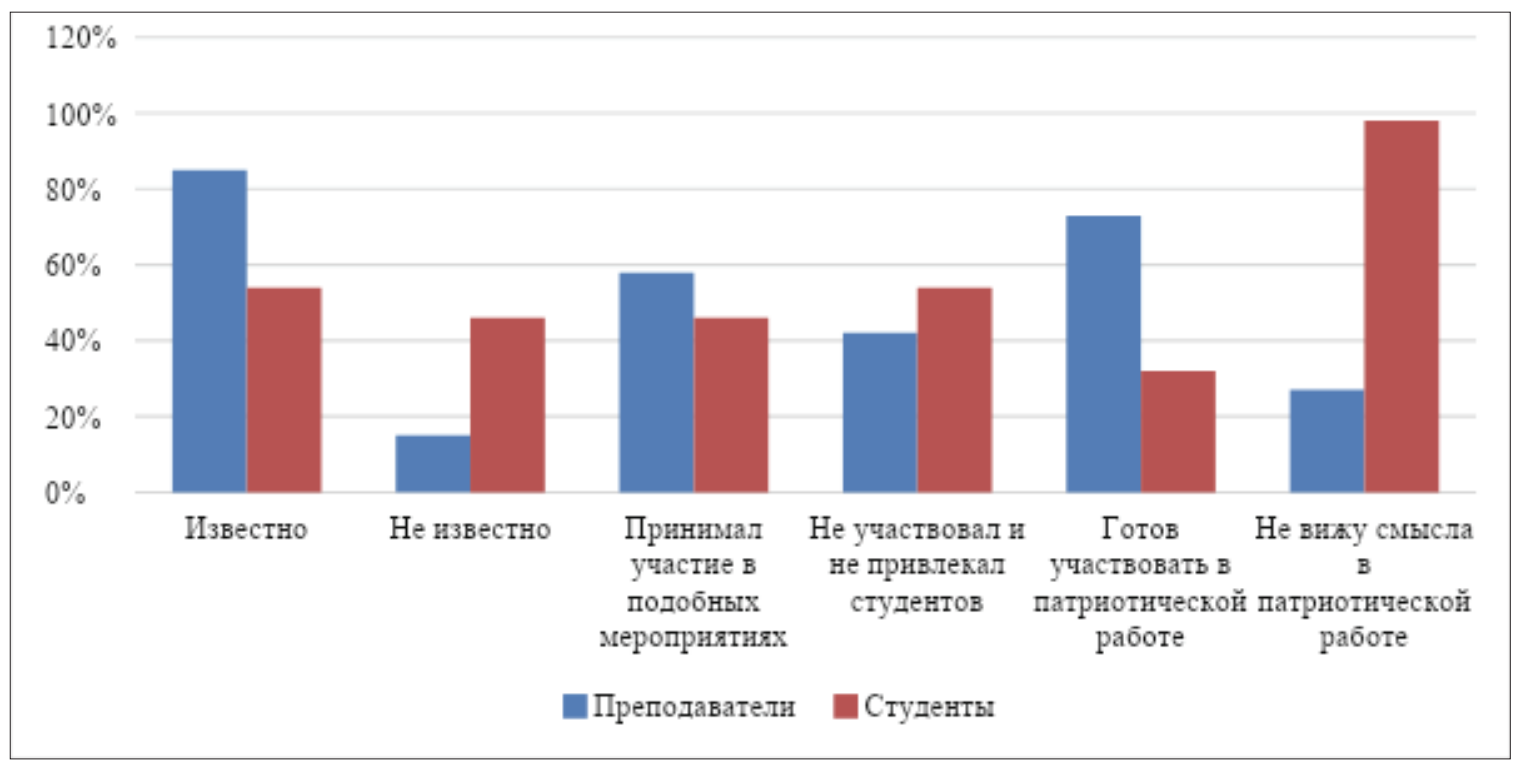

Рис. 4. Анализ мнений студентов и преподавателей относительно необходимости осуществления мероприятий по профилактике терроризма и кибертерроризма в образовательных учреждениях (2021 г.) 
В период с сентября по октябрь 2021 г. нами был проведен второй этап исследования — анкетирование студентов и преподавателей юридических специальностей СПО, вузов по проблеме определения их вовлеченности в антитеррористическую деятельность в условиях дистанционного обучения. Изменение темы исследования было осуществлено из-за практически повсеместного введения в 2020 г. дистанционного обучения в связи с пандемией новой коронавирусной инфекции, повлекшей ухудшение эпидемиологической обстановки в Российской Федерации и в Алтайском крае в частности [9, с. 18].

Методом случайной выборки было опрошено 107 респондентов - учащихся юридических направлений колледжей г. Барнаула (колледж АлтГУ, Алтайский промышленно-экономический колледж). Возраст респондентов 15-17 лет (рис. 5).

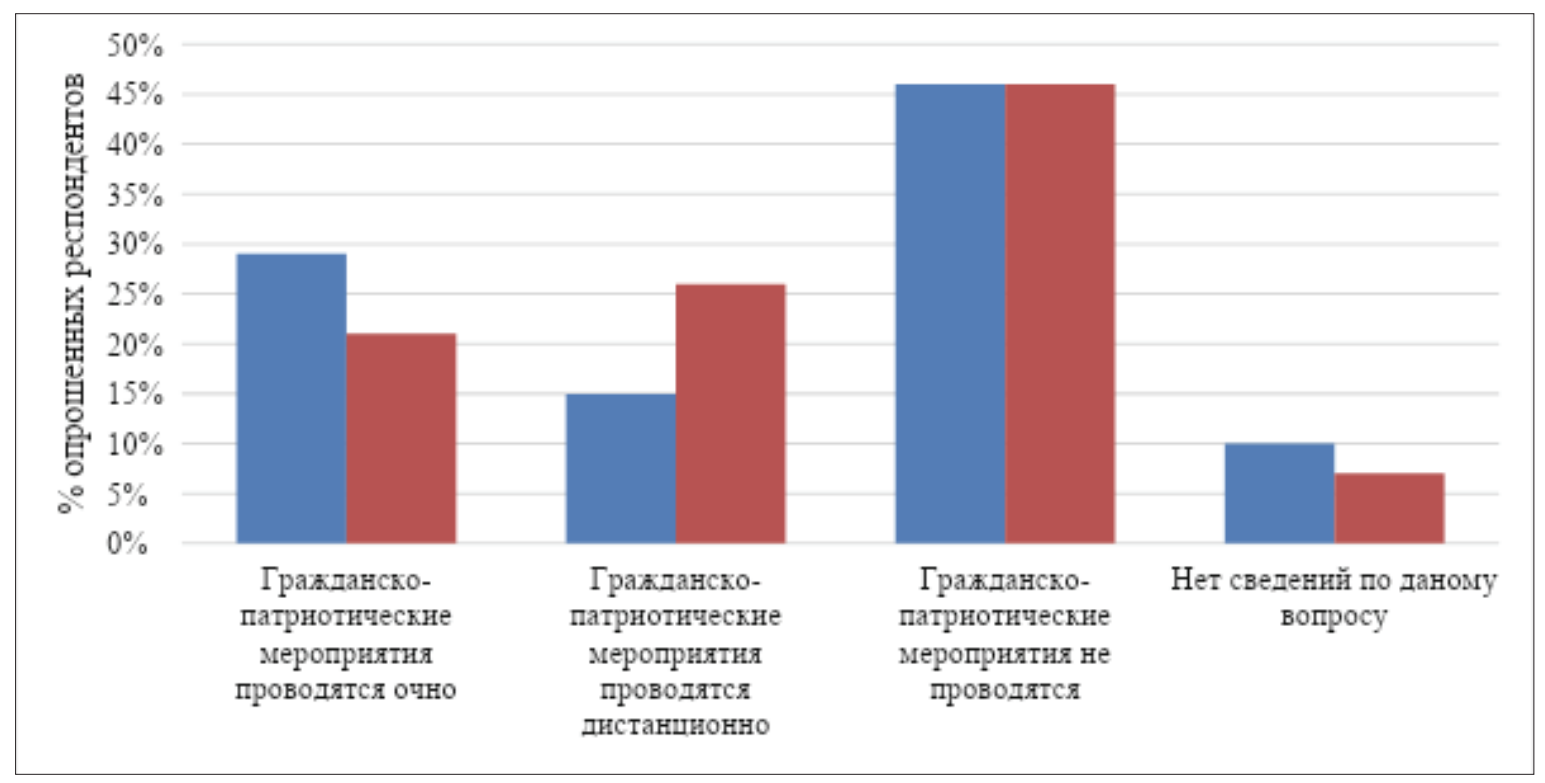

Рис. 5. Гражданско-патриотическая работа в учреждениях ВО и СПО в очном и дистанционном форматах (2021г.)

По данным исследования мы можем увидеть, что перевод обучения на онлайн-рельсы достаточно сильно ударил по уровню мотивации и собранности студентов, их готовности фактически самостоятельно осваивать большие объемы учебного материала. Естественно, дистанционный формат повлиял и на сферу гражданско-патриотического воспитания студенческой молодежи на базе колледжей и техникумов [10, с. 82].

Часть респондентов указала, что в их учебных заведениях проводятся мероприятия по противодействию идеологии терроризма и кибертерроризма, причем проводятся в очном формате. Сразу же можно отметить, что при очном проведении массовых мероприятий в период пандемии допускается одновременное размещение в одной аудитории не более 40 человек, что означает невовлеченность в подобные мероприятия большей части студентов СПО. Остальные сообщили, что подобные мероприятия проводятся в онлайн-режиме, и это указывает на постепенную адаптацию образовательных учреждений к дистанционному формату обучения. Однако пока достигнутый уровень адаптации недостаточен, поскольку 46\% респондентов сообщили, что гражданско-патриотические мероприятия по профилактике идеологии терроризма и кибертерроризма в их учебных заведениях не проводятся. Аналогичная ситуация прослеживается и на уровне высшего образования, где мы провели идентичное анкетирование среди студентов Юридического института ФГБОУ ВО «Алтайский государственный университет». Опрошены были студенты 1-4 курсов в возрасте от 18 до 22 лет. В анкетировании приняли участие 63 человека.

Когда мы реализовали первый этап исследования, похожая картина наблюдалась при опросе учителей и преподавателей, не соглашавшихся проводить в своих классах, кураторских группах якобы необязательные лекции и семинары по вопросу профилактики терроризма. При этом учащиеся о подобных мероприятиях были осведомлены. Сегодня ситуация изменилась, мы видим, что в усло- 
виях онлайн-режима обучения далеко не вся информация может быть вовремя доведена до сведения обучающихся, что говорит о затрудненном взаимодействии преподавателей и студентов на уровне СПО и ВО (рис. 6).

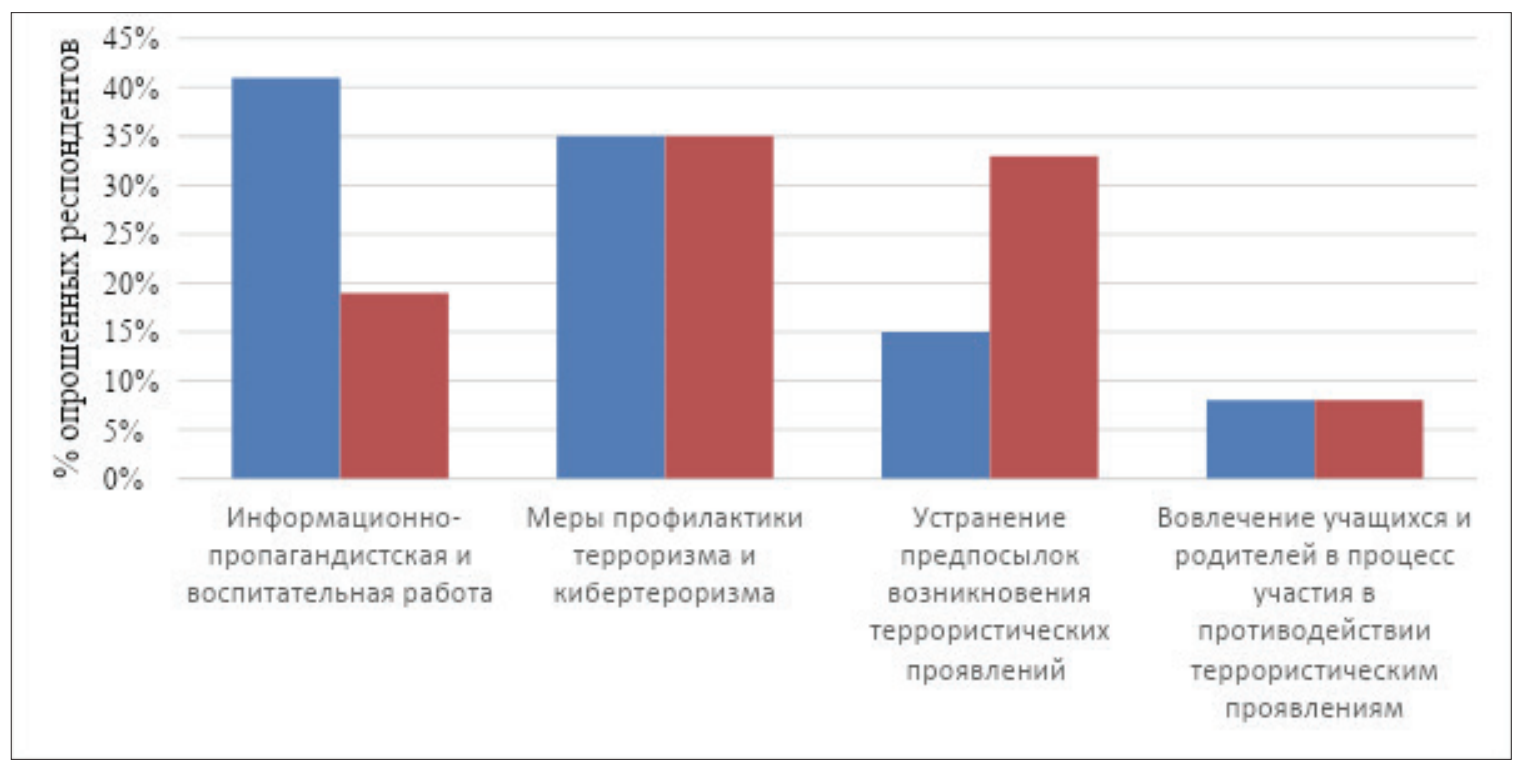

Рис. 6. Анализ мнений студентов ВО и СПО относительно содержания контрпропагандистской деятельности в общеобразовательных учреждениях (2021 г.)

$25 \%$ респондентов на базе СПО выразили желание участвовать в гражданско-патриотической работе, и это мы считаем основным результатом проведенных исследований. Можно проследить яркую динамику роста интереса молодежи к профилактике терроризма и кибертерроризма. Если на первом этапе исследования только $2 \%$ учащихся юридических специальностей СПО были готовы работать в антитеррористической сфере деятельности гражданского общества, то сейчас эта цифра выросла почти в 10 раз. 57\% затруднились с ответом на данный вопрос и 18\% респондентов ответили отказом, что означает необходимость продолжения работы в указанном направлении.

Это говорит о необходимости расширения рекламы антитеррористической деятельности среди молодежи. Представителям поколения «клипового» мышления нужен яркий бренд в звучной упаковке, и подобный эффект должен быть достигнут массированным продвижением хэштега «антитерроризм» на базе сайтов либо страниц юридических институтов в социальных сетях [11, с. 41].

На уровне студентов высшего образования также видна динамика роста интереса молодежи к профилактике терроризма и кибертерроризма от менее $2 \%$ до $32 \%$ за полтора года исследований. Однако 19\% сообщили, что не собираются участвовать в борьбе с терроризмом и кибертерроризмом, что показывает нам, по сути, поведенческий абсентеизм, осознанный и целенаправленный. Почти треть студентов бакалавриата не желает занять какую-либо активную гражданскую позицию в обществе, а с учетом популярности юридических специальностей и веса юриспруденции в обществе подобная ситуация недопустима и требует корректировки [12, с. 67].

На втором этапе исследования мы также провели опрос среди преподавателей юридических дисциплин колледжа АлтГУ и Юридического института АлтГУ. Опрошены 35 человек в возрасте 3550 лет.

Как ожидалось, рост вовлечения преподавателей в цифровую среду должен повлечь за собой рост правового просвещения и обучаемой ими молодежи. Этот тезис в полной мере подтверждается результатами нашего исследования.

\section{БИБЛИОГРАФИЧЕСКИЙ СПИСОК}

1. Анисимова И.А. Преступления террористической направленности: сравнительные аспекты. Барнаул : Изд-во Алт. ун-та, 2021. 122 с. 
2. Абазов К. М. Проблема использования современных информационно-коммуникационных технологий международными террористическими организациями // Вопросы безопасности. 2018. № 3. C. $1-9$.

3. Овчинский В.С. Кибермафия становится глобальным игроком. M., 2021. URL: https://zavtra. ru/blogs/kibermafiya_stanovitsya_global_nim_igrokom.

4. Бутусова Л.И. К вопросу о киберпреступности в международном праве // Вестник экономической безопасности. 2016. № 2. С. 48-52.

5. Чернядьева Н. А. Понятие «международный терроризм» в международных соглашениях ООН // Вестник СГЮА. 2012. № 4 (87). С. 1181-1187.

18. Greene A. Terrorism definition: one size fits all? // International and comparative law. 2017. № 66 (2). P. 411-440.

6. Рарог А. И. Уголовный кодекс России против терроризма // Lex Russica. 2017. № 4 (125). С. 155178.

7. Абдулатипов А. М. Понятие информационного терроризма // Юридический вестник Дагестанского гос. ун-та. 2019. № 2. С. 105-111.

8. Авдеев В.А., Авдеева О.А. Преступность террористического характера и экстремистской направленности в РФ: состояние и тенденции правового регулирования // Российский судья. 2018. № 8. C. $18-23$.

9. Обрывко Е.И., Стародубцева М.А., Саенко А.А. О некоторых аспектах повышения правовой культуры в вопросах профилактики экстремизма и идеологии терроризма в образовательной среде // Гуманитарные, социально-экономические и общественные науки. 2020. № 11. С. 81-84.

10. Мазуров В. А. Кибертерроризм: понятие, проблемы противодействия // Доклады ТУСУР. 2010. №1-1 (21). С. 41-45.

11. Цирлов В.Л. Правовые основы кибербезопасности Российской Федерации // Правовая информатика. 2013. № 4. С. 66-68.

УДК 347.132:004

ББК 67.404.04С51

\section{О СПОСОБАХ ЗАКЛЮЧЕНИЯ ГРАЖДАНСКО-ПРАВОВЫХ СДЕЛОК С ИСПОЛЬЗОВАНИЕМ ЭЛЕКТРОННЫХ ТЕХНИЧЕСКИХ СРЕДСТВ}

А.Р. Сулейменова

Алтайский государственный университет (Барнаул, Россия)

В статье рассматриваются вопросы заключения договоров с использованием электронных технических средств, освещаются современные тенденции и изменения в законодательстве в данной сфере. Автор исходит из того, что сделки с использованием технических средств имеют свои отличительные особенности, которые отражаются на их заключении. В статье представлены способы заключения сделок в электронном пространстве, а также возможные варианты действий, которые помогут обезопасить участников такой сделки.

Ключевые слова: сделки с использованием технических средств, форма сделки, электронный документ, электронная коммерция, электронные сделки. 